\title{
AN EXPLORATORY STUDY OF THE INTERACTION BETWEEN WORK AND PERSONAl LIFE: Experiences of South African eMPloyees
}

Authors:

Eileen Koekemoer ${ }^{1}$

Karina Mostert ${ }^{1}$

\section{Affiliations:}

${ }^{1}$ School of Human

Resource Sciences,

WorkWell: Research

Unit for Economic and

Management Sciences,

North-West University,

Potchefstroom Campus,

South Africa

Correspondence to:

Karina Mostert

email:

Karina.Mostert@nwu.ac.za

Postal address:

North-West University,

Private Bag x6001 (Box

202), Potchefstroom 2520

South Africa

Keywords:

experiences in the

workplace; experiences

in the personal life

work-personal life

interaction; consequences

of interaction; exploratory study

Dates:

Received: 01 Dec. 2009

Accepted: 14 June 2010

Published: 29 Sept. 2010

How to cite this article:

Koekemoer, E., \& Mostert,

K. (2010). An exploratory

study of the interaction

between work and

personal life: Experiences

of South African

employees. SA Journal of

Industrial Psychology/SA

Tydskrif vir Bedryfsielkunde,

36(1), Art. \#801, 15 pages.

DOI: 10.4102/sajip.v36i1.801

This article is available

at:

http://www.sajip.co.za

Note:

The material described in this article is based on work supported by the National Research

Foundation under reference numbers TTK2005081000025 and TTK2006061200018. This article was part of the first author's PhD thesis.

(c) 2010. The Authors. Licensee: OpenJournals Publishing. This work is licensed under the

Creative Commons

Attribution License.

\section{ABSTRACT}

Orientation: The interaction between work and personal life is an important field of research in the 21st century and of pressing concern for various individuals and organisations internationally and in South Africa.

Research purpose: The objective of this study was to investigate the interaction between work and personal life and the experiences thereof in the South African context.

Motivation of the study: South African employees are faced with various circumstances which could influence the interaction between their work and personal life and which could constitute different/unique experiences regarding this interaction.

Research design, approach and method: A non-probability purposive voluntary sample was used. Data collection was done by means of semi-structured in-depth interviews with 92 participants Content analysis was used to analyse and interpret the research data.

Main findings: Four main themes (i.e. the experience of work, experiences and domains in the personal life, interaction between work and personal life, consequences associated with the interaction) were extracted from the data. Participants indicated stressful and supportive aspects in their work as well as additional personal dimensions in their personal life. Interaction between work and various personal dimensions were indicated, as well as consequences associated with different types of interaction.

Practical and managerial implications: Individuals experienced interaction between their work and various other personal dimensions, where the forms of interaction were associated with certain consequences (i.e. spillover of emotions, energy depletion).

Contribution/value-add: Compared to international findings, unique findings were obtained relating to individuals' personal life and the consequences associated with the interaction.

\section{INTRODUCTION}

\section{Key focus of the study}

The key focus of this study is to explore the interaction between work and various other domains in an individual's personal life. One domain in the private life that has mainly received research attention is the family domain, where the majority of previous researchers recognised and used family life synonymously with personal life (Byron, 2005; Eby, Casper, Lockwood, Bordeaux \& Brinley, 2005; Mesmer-Magnus \& Viswesvaran, 2005). However, one's personal life also consists of other roles or domains apart from family life, for example religion, social and leisure domains that are important to individuals (Barnett \& Baruch, 1985; Holahan \& Gilbert, 1979; Lingard \& Francis, 2005; Pietromonaco, Manis \& FrohardtLane, 1986; Plaisier et al., 2008; Small \& Riley, 1990). This is also referred to as the saliency of roles. Since individuals are involved in multiple roles in their personal life, some researchers have suggested that conflict could arise between the work domain and these other specific roles or domains in their personal lives (Holohan \& Gilbert, 1979; Kirchmeyer, 1992). This conflict arising between the work domain and other non-work roles in individuals' lives might be due to the stressors, demands or a lack of resources that they are experiencing and might also contribute to different consequences or outcomes, depending on the various roles and the saliency thereof (Aryee, 1992; Holahan \& Gilbert, 1979; Keene \& Reynolds, 2005; Luchetta, 1995; Nasurdin \& Hsia, 2008; Plaisier et al., 2008; Voydanoff, 2005).

\section{Background to the study}

The interest in the interaction between work and family can largely be contributed to the dramatic changes that occurred in family structures, the nature of jobs, and organisations (Bailyn \& Harrington, 2004; Lewis \& Cooper, 1999; Lewis \& Cooper, 2005; Parasuraman \& Greenhaus, 2002). The growing representation of dual-earner families, single-parent families and families with elder-care responsibilities, the influx of women into non-traditional occupations and jobs and the increased involvement of men in the family domain are just some of the changes that have influenced family structures (Greenhaus \& Parasuraman, 1999; Stevens, Minnotte, Mannon \& Kiger, 2007). Technological and telecommunications advancements (e.g. portable computers and mobile phones) have made it possible for employees to work longer hours and to perform their job tasks at a variety of locations (Polach, 2003). Also, the constant need for upgrading household standards has driven people to work more in order to keep up with their own economic demands (Polach, 2003). As a result, the boundaries between work and non-work have become blurred, making a balance between work and private life a pressing concern for women, men, families and organisations. 
Work is a domain that is salient in many individuals' lives - not only do people work for the fulfilment of their economic needs and desires, but also to provide them with a sense of identity and opportunities to engage in meaningful relationships with others (Lewis, Rapoport \& Gambles, 2003; Thompson \& Bunderson, 2001). Many people view work as the centre of their lives, the means to structure their lives, their contact with social reality and the achievement of status and self-esteem (Haworth \& Lewis, 2005). However, the labour market is becoming increasingly competitive and the pressure is high on employees to perform. As a result, paid work is becoming highly intrusive into other aspects of employees' personal lives (Lewis et al. 2003). Not surprisingly, a steady stream of research has been produced over the past 25 years with regard to the interaction between work and other domains in employees' lives (Allen, Herst, Bruck \& Sutton, 2000; Bulger, Matthews \& Hoffman, 2007; Frone, 2003; Geurts \& Demerouti, 2003; Greenhaus \& Beutell, 1985 Greenhaus, Collins \& Shaw, 2003; Kirchmeyer, 1992; Lewis et al., 2003; Olson-Buchanan \& Boswell, 2006).

\section{Research Purpose}

\section{Trends from the research literature}

Over the past years, various centres of interests have been highlighted in work and family overview studies (see Eby et al., 2005; Lewis \& Cooper, 1999). These areas of interests include the changing nature of work, work role stress, work schedules and changing work patterns, career outcomes, gender roles within the work and family domains, work-family relationships in dual-earner couples, multiple social roles of employees, organisational strategies relating to work-family assistance, work-family linkages and relationships among life domains. Developments in the field of work and family research have mainly been studied within an integrative framework set by international researchers, where the majority of research focused on the measurement, the direction of interference, antecedents and consequences relating to the interaction between work and family (Allen et al., 2000; Bellavia \& Frone, 2003; Frone, 2003; Geurts \& Demerouti, 2003).

Although some researchers have recognised that various domains of an individual's life interact with one another (Frone, 2003; Kirchmeyer, 1992), the greater part of international research has focused on the measurement of conflict that arises from simultaneous pressures experienced in both work and family domains (commonly known as work-family conflict (WFC), see Greenhaus \& Beutell, 1985). Also, the directionality of dimensions influencing each other (i.e. work influencing the family domain and the family influencing the work domain) has substantially been addressed by various researchers (Carlson, Kacmar \& Williams, 2000; Curbow, McDonnell, Spratt, Griffin \& Agnew, 2003; Geurts et al., 2005; Grzywacz \& Marks, 2000; Hanson, Hammer \& Colton, 2006; Mesmer-Magnus \& Viswesvaran, 2005; Netemeyer, Boles \& McMurrian, 1996).

In the work-family literature, various researchers have classified previously researched antecedents into three main categories - that is, demographic and personal characteristics (e.g. gender, age, family status, negative affectivity, personality), family or non-work characteristics (e.g. social support, parental stressors, family role ambiguity, family stressors) and work- or job-related characteristics (e.g. work stressors, work demands, hours spent at work, job stress, job support, flexibility at work) (Ballout, 2008; Bellavia \& Frone, 2003; Byron, 2005; Geurts \& Demerouti, 2003). In addition, various consequences have been studied that relate to the interaction between work and family, including physical, psychological, behavioural, attitudinal and organisational consequences (Geurts \& Demerouti, 2003). Other researchers classified the consequences differently as workrelated consequences (e.g. job satisfaction, turnover intension), nonwork-related consequences (e.g. life satisfaction, marital satisfaction) and stress or general health-related consequences (e.g. burnout, somatic or physical symptoms) (Allen et al., 2000; Bellavia \& Frone, 2003; Frone, 1992b; Frone, 2003).

\section{Research Objectives}

From the above, it is clear that there is a need to explore the interaction between work and personal life for employees within the South African context distanced or separate from the integrative framework provided by international researchers. The main objective of this study is thus to explore the interaction between work and all other life domains and to gain insight into the experience and views of work-personal life interaction in the South African context.

\section{The potential value-add of the study}

Even though a variety of work-family studies have been done in South Africa, the majority of these studies were crosssectional quantitative studies. These studies, in accordance with previous international research trends and integrative frameworks, focused on the prevalence of work-family interaction (Rost \& Mostert, 2007), demographic differences (Coetzer, 2006; De Klerk \& Mostert, 2010; Mostert \& Oldfield, 2008; Pieterse \& Mostert, 2005), psychometric properties of WFC instruments (Marais, Mostert, Geurts \& Taris, 2009; Pieterse \& Mostert, 2005; Rost \& Mostert, 2007), possible antecedents and wellbeing outcomes of WFC (Koekemoer \& Mostert, 2006; Mostert, Cronjé \& Pienaar, 2006; Mostert \& Rathbone, 2007; Patel, Govender, Paruk, Ramgoon, 2006). With only a few additional studies exploring the occupancy of multiple social roles and role salience, along with limited qualitative studies (Donald \& Linington, 2008; Mclellan \& Uys, 2009), very little is known about the specific way in which employees in the South African context experience the interaction between their work and personal life, for example as opposed to employees from other societies and social contexts.

Although research has progressed substantially over the past decades, studies on work-family interaction originated mostly from Western societies, notably the USA and Europe. Much work remains to be done in order to develop a comprehensive understanding of the complex relationships between work and family life within various other social contexts and societies, including South Africa. According to Cariku (2002), understanding the effects and interaction between work and personal life across cultures and societies has become increasingly important, especially since employees from different societies and cultures may experience their work environments and areas in their personal life very differently, which may contribute to different types of interaction.

\section{What will follow}

In the section to follow, work and personal life will be explored by means of a qualitative approach. Results will be discussed where various themes regarding the interaction between work and personal life of South African employees will be presented and discussed.

\section{RESEARCH DESIGN}

\section{Research approach}

In this study, a qualitative research design with an exploratory approach was used to explore and describe the interaction between participants' work and all facets of their personal lives. With qualitative studies, researchers attempt to understand the world from the participants' point of view and unfold the meaning of people's experiences to their lived world prior to any scientific explanations (Kvale, 1996). According to Salkind (2009), the purpose of qualitative research is to examine human behaviour and the social, cultural, and political contexts within which it occurs. Qualitative studies are based on meanings expressed through words and other symbols or metaphors and the designs most often used include case study research, participant observation, unstructured in-depth interviews, focus groups and participatory research (Welman, Kruger \& 
Mitcherll, 2005). A qualitative approach is especially beneficial to this study since participants are allowed to describe what is meaningful or important to them in their own words rather than being restricted to predetermined categories regarding work-personal life interaction. This study is located in the post-positivism paradigm within the broad field of qualitative research (Guba \& Lincoln, 1994). The methodology used in this paradigm aims to enquire information in more natural settings, collecting more situational information, and determining the meanings and purposes that individuals ascribe to their actions.

\section{Research method}

\section{Sampling}

A non-probability purposive voluntary sample was taken from 92 South African employees from four different occupational groups (i.e. police officers, secondary educators, mineworkers and university academic staff) within the North-West and Free State Provinces. Although employees were chosen in a non-random manner, inclusion criteria were implemented to ensure a more representative sample of different cultural or language groups. These inclusion criteria determined that a participant should, (1) have been employed in one of the selected occupations, (2) have been working for at least two years in the specific occupation, (3) have been able to communicate in Afrikaans, English or Setswana and (4) have given written consent to participate in the interviews. The White group consisted of Afrikaans-speaking participants, whereas the African group included Setswana-, isiXhosa- and Sesotho-speaking participants. The isiXhosa- and Sesothospeaking participants preferred to be interviewed in Afrikaans. The sample size in each occupational group was directed by the number of participants willing and accessible to participate, and interviews continued until data saturation was reached after 92 interviews (Burns \& Grove, 1997).

\section{Research setting and establishing researcher roles}

Prior to data collection, it was important to establish the research setting, which included determining the research field and gaining permission to enter the field of research. According to De Vos, Strydom, Fouche and Delport (2005), the specific field in which the inquiry is to be undertaken, is directly linked to the choice of problem. The research field was determined by identifying high-risks groups regarding stress experienced in their work environments. This identification was done based on previous literature in South Africa, where the following industries were identified: South African Police Service, the educational sector (i.e. secondary and tertiary institutions) and also the mining industry (Jorgenson \& Rothmann, 2008; Mostert, Rothmann, Mostert \& Nell, 2008; Mostert \& Oldfield, 2008; Oosthuizen \& Berndt, 2008; Pienaar \& Rothmann, 2006). Therefore, prior to the interviews, written consent to conduct the research within these four occupational groups was obtained from management bodies in the various organisations (i.e. police stations, schools, mines and universities). The participating police stations and secondary schools were located within the North West Province, while the participating mine and university were located in the Free State Province.

According to De Vos et al. (2005), maintaining proper relationships with the participants is of great importance and will largely determine the accuracy and reliability of the information gathered. Since some participants may view researchers as intruders, it is advisable for researchers to begin relationships somewhat unobtrusively, rather than being too involved from the start. For this reason, within each of the participating organisations a person was identified to assist the researcher and to act as inter-mediator in the research process. The role of the inter-mediator was to identify employees willing to participate in the research and to provide the researcher with the necessary contact details and other biographical information. With the assistance of the inter-mediator, participants were informed of the objectives and procedures of the study. They consented in writing, after which interviews were scheduled on dates that suited each of the participants. Other ethical issues were also communicated beforehand to the participants with the assistance of the inter-mediator and also during the interviews (i.e. deception, right to withdraw and confidentiality) (Willig, 2008).

Although the interviews took place where it best suited the participants, special attention was given to the climate/ atmosphere of the room and to establishing a relaxed environment. In order to ensure privacy and no interruptions during the interview, a 'do not disturb' sign was put up outside the door. At the outset of the interviews, the participants were put at ease by the friendly and warm manner in which the researcher introduced herself, after which the researcher explained the context of the interview. Permission was obtained for the use of tape-recorders. Participants were informed that they could withdraw from the study at any time.

\section{Data collection methods}

Data collection was done by means of semi-structured interviews with participants from the various occupational groups. Prior to the interviews, an interview schedule was developed and evaluated where only one broad open-ended question was included in the interview schedule ('You have a work and a personal life. Can you describe how you experience the interaction between your work and all facets of your personal life?'). This question was asked once rapport had been established and the participants felt comfortable and open for conversation. In conjunction with the open-ended question, the researcher used communication techniques (such as minimum verbal response, paraphrasing, reflection, clarifying and summarising) to encourage elaboration (Okun, 1992). Depending on the language preference of the respective participants, interviews were conducted in Afrikaans, English or Setswana. In addition to verbal information that was obtained during the interviews, researchers also took observation notes of participants' behaviours throughout the interviews. These observation notes included the manner in which the participants acted or reacted when answering the questions as well as their behaviour during the interview (e.g. being distant when asked questions and long pauses). According to De Vos et al. (2005), observation notes (also referred to as field notes) contain a comprehensive account of the participants, the events taking place, the actual discussions and communication. Comprehensive observation notes enable the researcher to maintain maximum control over the situation.

\section{Recording of data}

With the permission of participants, interviews were audio taped and transcribed verbatim for further analysis. In order to ensure confidentiality the corresponding transcriptions and tapes were labelled using specific coding according to occupation and language groups where participants were allocated a specific number within their occupational group (e.g. PA1 - Police-Afrikaans-participant 1; TA1 - TeachersAfrikaans-participant 1; MA1 - Mine-Afrikaans-participant 1; EA1 - Educators-Afrikaans 1; in the case of English language codes were PE1, TE1, ME1, EE1 respectively; for Setswana, codes were PS1, TS1, MS1, ES1). Only the researchers involved had access to these coding schemes which ensured privacy for the participants. This coding is also used in the referencing of quotes further in the article. Participants were informed that the tapes would be kept in a safe place as part of recordkeeping after completion of the research and that their identity would remain anonymous. Interviews conducted in Setswana were translated into English by an accredited translator. Throughout the process, attention was given to the rights of the participants (right to privacy, right to anonymity, right to fair treatment, and right to protection from discomfort and harm) (Burns \& Grove, 1997). 


\section{Data analyses}

For the purpose of this study, the verbatim transcripts were analysed by means of content analysis. According to White and Marsh (2006), content analysis is a research technique used to make replicable and valid inferences from text or meaningful matters. Content analysis in qualitative research focuses on and gives attention to content or contextual meaning of the tex (Hsieh \& Shannon, 2005) and was therefore applicable to this study. While analysing the data, close adherence were given to methods described by a number of previous authors (Appleton, 1995; Burnard, 1991; Hsieh \& Shannon, 2005; Weber, 1990). To obtain an overall picture of the context, interviews were read thoroughly several times, after which the actual text was condensed into meaningful units (sentences or paragraphs) that emerged from the responses of the participants regarding their experiences. Subsequently, all these meaningful units were sorted or categorised into major themes. From these broad themes, similar smaller themes and words were explored and summarised, resulting in various sub-themes. Although observation notes were taken during interviews (and were examined as part of the data analysis process), no significant new additional meaning or value was obtained from the observation notes and no contrasting findings or evidence was suggested in the notes. According to De Vos et al. (2005) researchers will not necessarily utilise all observation notes in the final report, but it is better to have adequate information as researchers can use the observation notes to decide if additional value was added.

In order to overcome concerns regarding rater bias in the critical stages of content analysis, the suggested steps for creating, testing and implementing a coding scheme as developed by Weber (1990) were closely adhered to. In this study, two researchers (the authors) were independently involved in the data analysis, and one of the researchers acted as co-coder. The steps described by Weber (1990) were discussed beforehand between the researcher and co-coder as part of the data analysis and coder agreement and included defining the recorded units, defining the coding categories, testing the coding on a sample of text, assessing the accuracy of the sample coding, revising the coding rules, and the coding of all the text. During an open and critical evaluation, all themes and the analysis process were discussed between both authors until consensus was achieved. Finally, the themes were refined and a consensus discussion clarified the main themes and sub-themes. As part of the data analysis, a literature control was conducted in order to compare and contrast the findings of the research with similar studies, which is presented in the discussion.

\section{Strategies employed to ensure quality data}

In addition to observation notes, the trustworthiness of the findings was also ensured by attending to the principles of credibility (checking the truth value of the findings), transferability (ensuring applicability of the findings), dependability (ensuring consistency of the findings) and conformability (which was accomplished by using the criterion of neutrality or freedom from bias) (Appleton, 1995; Guba, 1981; De Vos et al., 2005). According to Appleton (1995), researchers could adhere to these principles by means of, (1) going back to participants to discuss interpretations of the findings (truth value), (2) asking other expert researchers to read through some transcripts independently and to identify themes to confirm the agreement between researchers (applicability), (3) carrying out pre-pilot interviews to develop interviewing skills (consistency) and (4) clearly describing each stage of the research process and explaining what was done and why (neutrality). During this study, these principles were adhered to by means of peer examination and independent coding, the dense description of the data, keeping of the raw material and applying the same procedure throughout, triangulation, peer examination and the code-recode procedure.

\section{Reporting}

In the findings that follow, each of the main broader themes that emerged from the data will be described separately, indicating more specifically how respondents experienced each of the main themes. For illustrative purposes, selected quotes (interview excerpts) that contain the experiences of respondents and that are typical of other responses were used (referencing was also included based on the coding reported in recording of data). Some modifications were made to the interview excerpts below in order to make the excerpts easier to grasp. These modifications were made without affecting meaning and only involved the omission of words in order to achieve a more compact statement as well as the omission of 'nonsensical' noises such as ' $\mathrm{hmm}$ ' from quoted text (Lombaard \& Mouton, 2005; Weiss, 1994).

\section{FINDINGS}

From the data analysis of the interviews, four main themes were identified - that is the experience of work, experiences and domains in the personal life, the interaction between work and domains in the personal life, and the consequences associated with the interaction. These themes are described in detail below.

\section{Theme 1: The experience of work}

The first and strongest theme that emerged from the responses was participants' experiences in their work environment. From the responses, it was evident that participants experienced certain aspects of their work as stressful, while other aspects were seen as more supportive. Subsequently, these aspects were categorised as stressors at work and resources at work. Table 1 shows the different stressors and resources as described and experienced by the participants. For illustrative purposes, associated keywords are also shown as mentioned by the participants.

\section{Stressors at work}

Participants were confronted with a great deal of work-related pressure and time constraints - to such a degree that feelings of overload became present and the quality of their work seemed to be compromised. A large number of participants experienced taxing and strenuous demands in their work environment, while their personal problems were often seen as unimportant and insignificant. In addition, expectations were set for workers to deal with other people's personal problems and provide support for various groups of people in their work environment and community. Sometimes participants were expected to do work that was not their responsibility. The following example can be provided to illustrate some of the above-mentioned stressors:

They give you so much work to do at a time. While you are busy with that task, something else comes up. Then you are expected to abandon that task and carry out the next one. As a result, you end up working overtime or you are behind with your work because you have not completed the tasks given to you initially. We have too much work and so little time to do it. Everyone expects you to complete their tasks and is pushing you all the time. Then I don't do my job to the best of my ability.

(participant PE11)

In addition to the strain and tension that participants experienced with regard to their workload, they were also confronted with inner conflict that arose from aspects such as unfair promotions, poor remuneration, irregular and long hours, overtime and shift work. As a result of working long hours and overtime, without receiving the necessary recognition, remuneration or promotions, participants became demoralised and negative towards their work situation and colleagues. As a result, they began to question their own value as well as the value of their work. Feelings of disrespect and distrust towards their superiors began to emerge as a result of unfair or unreachable promotions, which in turn caused additional tension and conflict between participants and their superiors/colleagues. The following quote from a police officer 
TABLE1

Experiences in the Work Environment

\section{Sub-theme} Associated keywords

\section{Stressors at work}

Pressure, overload and workload

Stressful working arrangements

Strenuous relationships at work

Nature of the job

Not being valued in an unsupportive work environment

\section{Resources at work}

Occupation satisfaction

Supportive working arrangements

More responsibilities; Making difficult decisions; High workload; Time constraints; Heavy work demands.

Irregular and long hours; Overtime work; Shift work; Unfair promotions; Poor remuneration; Heavy work schedules.

Managing different people's attitudes; Conflict with co-workers; Difficult parents (in the case of teachers*); Difficult co-workers and/or supervisors; Interacting with different role players with different views and opinions; Dealing with negative attitudes of people.

Dangerous working conditions (in the police*); Exposure to traumatic situations; Lack of resources; Difficult class situations (in the case of teachers*); Dealing with abused or raped children (in the police*).

Oppressive work environment; Top-down commanding approach (in the police ${ }^{\star}$ ); Lack of empowerment, recognition, support, or appraisals; Lack of support for personal problems; Lack of communication channels and strategic planning.

Enjoying your work; Passion for your work; Understanding the purpose of your work; Experiencing work engagement; Showing love and care for the children (in the case of teachers*).

Flexible working hours; Extra remuneration for working overtime; Help from temporary workers; Working better shifts.

Good interpersonal relationships; Support and help from co-workers/supervisors; Mutual respect and understanding between colleagues; Friendships at work.

*Some stressors are more specific to certain occupations and are indicated in parentheses.

serves as illustration:

Take for example promotions: you want to know the reasons for not getting promoted, but you are treated inappropriately. Then someone less capable than you gets promoted. These are the things that demoralise us. You end up thinking, it is actually better to stay home than be at work. I end up being demoralised so much that I do not want to go to work when I leave home.

(participant PE8)

\section{Another statement follows:}

I start to convince myself that maybe that is how things have to be for me, not getting promoted. It is their decision not to promote me and I cannot do anything about it. You lose respect and trust towards the high-ranking officers, and this causes conflict between us.

(participant PE 10)

Some participants also experienced the nature of their job as stressful, specifically in the case of police officers and teachers. One police officer mentioned:

The other thing that stresses me at work is that you could find that I deal with traumatising cases. Especially rape cases whereby you find a child being injured. I see many things that break my heart which give me stress. You work with so many different characters of people, which are straining as well.

(participant PE1)

One teacher also described the nature of her job as stressful:

I am teaching a class. The department tells us that we have to give all the children attention. But it's difficult with fifty or more children in the classroom. You can't give individual attention. It's not possible. It's difficult again, it's like a class that is dirty, it's the facilities again, and it is also the children's attitude and when you enter the class its dirty again.

(participant TE2)

The lack of being valued and respected as individuals and employees was also mentioned as a stressor at work. Some participants felt that they were treated as numbers or impersonal objects instead of human beings. This resulted in feelings of low self-worth, as the following quotes from police officers illustrate:

The problem is actually at work - our managers do not have our interest at heart. They only like you when they have something to benefit from at the office. However, when you have problems they are not interested in you.

(participant PE5)

Some participants also experienced the bureaucratic structure of the organisation, the lack of support from management and the oppressive work environment as stressful. As one police officer mentioned:

The thing is those at the top oppress those at the bottom; they want those that are at the bottom to feel that they are at the bottom. On top management side, they still use a harsh decision and approach. (participant PE1)

\section{Resources at work}

Although participants experienced negative aspects in their work, several participants mentioned that - even in the face of difficult work circumstances - they also experienced resourceful and supportive aspects. The first intrinsic/inherent aspect mentioned was their feelings of satisfaction, enjoyment and passion for their occupation. In some instances this passion was such that participants referred to their work as a calling, and not only as a means that allowed them to reap monetary rewards. This type of resource seemed to be internal to the participant and manifested itself through participants' positive attitudes, love and care with which they performed their work (described as 'wholeheartedly'). The following quote illustrates this attitude:

I like this job and that is why I perform it wholeheartedly. (participant PE1)

I enjoy my work very much - it is really nice and challenging for me. I have worked at this company for 30 years, and I still enjoy my work.

(participant MA1)

I love my work - that's what I can tell you, I like my job [laughter]. I like my job even though I travel from Johannesburg to Potchefstroom every day.'

(participant TE8)

To be a teacher is a calling, since I am so close to God, and I know he has given me the right job. I want to say that I really live my life to the fullest. I believe it is a calling and what God wanted. From that perspective you cope and you handle problems differently.

(participant TA7)

In addition to the internal feelings of satisfaction and love for their work, participants also seemed to experience support, which either originated from supportive working arrangements or supportive relationships at work. These resources provided participants with the ability to deal with the more strenuous aspects in their work environment. Participants indicated that having supportive relationships where people have mutual respect for each other was very important. More structural arrangements at work, such as working flexitime, having 
temporary workers to help, and being able to manage one's own time at work, were also regarded as helpful resources. The following quotes illustrate the resourceful and supportive aspects in participants' work environment:

It boosts us to have support from our co-workers. Furthermore, support you get from maybe a co-worker who has a family problem and you can relate to the story he or she has. Then as a friend and a co-worker we can sit down and advise each other - or we can refer each other to the relevant person or we can go to the station commissioner. The station commissioner can help where he can to support a co-worker who has a problem. So all in all we do get support.

(participant PE9)

\section{Theme 2: Experiences and domains in the personal life}

In the second theme that emerged from the responses, participants emphasised their personal life. Table 2 illustrates the different dimensions that formed part of participants' personal life.

Firstly, a very strong family dimension emerged from the responses, indicating the importance and value of the dimension. The family dimension included various family members (e.g. spouse, parents, and children) and the responsibility that participants had towards them. Although participants experienced family responsibilities as strenuous at times (the pressure to assist with problems that other family members may experience, the pressure to spend time with family while occupied with other activities, the high expectations that family members have towards the role of participants in the family, etc.), some participants seemed to experience their family life as a safe haven away from work, where they not only gave support to family members but also received support. This support originated mainly from the spouse or parents. Whether it entailed more practical support (having a spouse/partner to help with the demands of raising children or with domestic matters) or more emotional support (having a spouse/partner who understands your work situation), participants indicated the meaning and value of this supportive role:

Your home life is a type of safe zone away from what is going on in your working environment.

(participant EA2)

Yes, they help me-my husband helps with the food in the evening if I have to go to work. He makes sure that the children are in bed on time, and awakens them in the morning, and makes sure they get to school.

(participant MA11)

I have a lot of help, I really have a wonderful husband that stands by me.

(participant TA9)
For me it is not difficult, because, I have someone who are at home during the day, I am a single parent, and my parents stay with me, so they stay with my child. If I come home from work I can do the house chores.

(participant ME7)

As a result of the responsibilities toward the well-being of their family members, participants were confronted with both domestic matters and matters relating to caring for their children, which both formed part of their home life. It seemed that in addition to participants' responsibilities at home (which included house chores such as cooking, cleaning, doing laundry, preparing meals), participants also have to attend to the needs and demands of their children (helping them with homework, putting them to bed, etc.). Some participants indicated that they had domestic workers to assist with the responsibilities in the house or with activities related to the children, a great source of support to deal with the challenges in this dimension.

Sometimes I come home much stressed and then there is lots of work to do. I am a mother, with a boy in grade 1, where I have to help him with his homework. And then I also have to cook and do all those things, it is really stressful.

(participant MA8)

... but I always like to be home on time to do the cooking. You know you've got to cook and then you are a wife and a mother and then you have a career and you still have a social life. It is a lot of responsibilities.

(participant EE5)

Apart from their involvement with family members and taking care of domestic matters, participants also mentioned other dimensions in their personal life, including religious/spiritual activities, focusing on themselves, exercising, socialising with friends or colleagues, taking responsibility for members in their extended family and community, or studying. Participants emphasised the value and meaning of these various dimensions and mentioned that involvement in other activities fulfilled certain needs, goals and aspirations. It also offered various forms of support, meaning and opportunity for growth.

Also of particular importance was the religious or spiritual dimension. In the literature, the distinction between religion and spirituality has given rise to various views (Elkins, 1988 Emmons, 2006; Hill et al., 2000; Marler \& Hadaway, 2002; Pargament, 1999; Zinnbauer, Pargament, Cole \& Rye, 1997; Zinnbauer, Pargament \& Scott, 1999), which do not feature within the scope of this study since it was not possible to know from the responses what participants meant by religion or spirituality or how they viewed the distinction between the two concepts. More important, however, was the existence and significance of such a personal dimension. This was a rather complex dimension since participants not only indicated their involvement or participation in religious activities, but

TABLE 2

Experiences in the Personal Life

\begin{tabular}{ll}
\hline Sub-theme & Associated keywords \\
\hline Family & $\begin{array}{l}\text { Involvement and interaction with family members (family includes parents, spouses/partners and children). } \\
\text { Domestic responsibilities }\end{array}$ \\
$\begin{array}{l}\text { Taking care of children (e.g. getting ready for school, bathing, putting children to bed); doing house chores (e.g. cooking, cleaning; doing laundry, } \\
\text { preparing meals). } \\
\text { Religion / Spirituality }\end{array}$ & $\begin{array}{l}\text { Attending church activities; believing in God; praying; practising religious activities (e.g. attending prayer meetings, attending Bible study groups). } \\
\text { Self }\end{array}$ \\
Socialising & Spending time with friends; going out with friends or colleagues; taking time to relax with friends; socialising with people outside your work. \\
Exercise & Being active in a gym; participating in sports activities such as athletics, netball, rugby, tennis, football, soccer; participating in running and jogging. \\
Leisure activities & Participating or pursuing activities outside work such as gardening, farming, and taking painting lessons; practising a hobby outside work. \\
Extended family & Taking responsibility and care for relatives (relatives included cousins, aunts, brothers, sisters and their children). \\
Community activities & Doing community work; trying to empower the community; receiving support from community members. \\
Studies & Pursuing studies outside work. \\
Work (second job) & Pursuing a second job after hours. \\
\hline
\end{tabular}


also mentioned the supportive role of religion. Although participants mostly referred to specific religious activities (e.g. going to church, going to prayer meetings and attending Bible-study groups), they also mentioned that their religious beliefs served as a resource or coping-strategy in their general life. Participants indicated that when faced with difficulties or problems, their strong religious beliefs helped them in managing or coping with adversities:

You know I am a highly religious person and have a lot of problems. Whatever problems I am faced with - life will not get me down because I usually pray and the Lord answers me. This is the reason I am not in real trouble most of the time. I believe in God and I believe the Lord does help me.

(participant PE2)

I pray and God helps me - believe me, I am a Christian, a reborn Christian, and that's why I have a thought of believing that He is my God.

(participant TE6)

Others mentioned that they experienced their work as a calling, where they pursue work specifically to make a difference in the world. Participants indicated that they found meaning in their work, as they viewed work as a calling in life. The following quotes illustrate the meaning of the religion/spiritual dimension:

For me as a person my work is a calling, it is what God wants me to do. I think from that perspective I cope, and then I handle my problems differently.

(participant TA9)

Several participants indicated a need for personal time. Additionally, there was a very strong need to pursue activities or aspects which are beneficial to their own well-being, including exercising and spending time on leisure activities:

Sometimes I use the time I have to myself to reflect upon what I do, where I am, otherwise I lose track of myself. It is important for me to spend time by myself.

(participant MA5)

I think I should be spending more time exercising - that's for me - or maybe go to a beauty spa for a massage. Taking care of myself physically because that is important.

(participant EE5)

Most of the time I exercise, I jog, I run. I even do minor exercises at home in the morning and in the afternoon.

(participant PE1)

Then for a hobby I did carpentry in the afternoons, over weekends and during the holidays - that was nice.

(participant TA3)

For many participants, socialisation with colleagues and friends served as a support system or emotional outlet. Many used relationships and interaction with other people to relieve stress or for personal development. The following quotes illustrate the social outlet or support that individuals gain from their involvement in certain social contexts:

I'm a person that always likes to chat - have a laugh or twoor hang out with friends and relax. I enjoy inviting friends over during the weekend to have a braai - to sit and chat.

(participant PE4)

I talk to my friends about issues of concern to them and me. Sometimes you find that they have the same problems and you get their views.

(participant PE8)

Apart from the above-mentioned personal dimensions, some participants also indicated that they had an obligation to take care of extended family (cousins, aunts, brothers and sisters) and community members (friends, neighbours or other individuals in their community). However, this responsibility towards extended family and community members was only mentioned by African participants and not by any of the white participants. Thus, for the African participants, contributing and taking responsibility for these members was very important and meaningful, but at the same time very strenuous. This is mainly because it was expected from them and caused a great deal of financial strain. In some cases they were also expected to provide a home or shelter:

In my life at home, I am not only married, but I am also the breadwinner. I look after my brother (who stays with me) as well as my sister's daughter - who is still in school.

(participant TE3)

My sister's children, my child, and my brother's child are staying with me.

(participant TE6)

Lastly, some participants were also studying (which provided personal meaning, value and growth) or had another job after hours. For many participants, studying entailed extra time pressures relating to assignments and studying for exams, while for other participants consulting work as an additional job also implied additional time pressures and work.

Yes the children are in grade 4, and with the maid not here, you have to do that work also, and then I also have FLM course. I am writing exam, we are doing it through Unisa, so I have to submit assignments and study and at times it is really rough.

(participant MA10)

Having a second job, which is doing consultation work for companies or starting an own practice, which takes more time away from work because you have responsibilities towards your other job.

(participant EA1)

In addition to the meaning and value that participants experienced in each life dimension, it also seemed that involvement in certain dimensions provided some resources that served as coping mechanisms to deal with stress. Participants suggested the supportive role of family (e.g. having a supportive husband or a domestic helper), religion (e.g. prayer and believing in God as a way of coping), socialising (e.g. going out with friends to unwind) and exercise (e.g. going to the gym as stress reliever).

\section{Theme 3: Interaction between work and domains in the personal life}

The third major theme entailed different forms of interaction between work and personal life, which took on a specific direction of influence. Table 3 indicates the various forms of interaction and the meaning participants attached to these.

The first form of interaction participants mentioned was the influence of work on their personal life. It seemed that due to strenuous demands and responsibilities at work (e.g. working overtime or working long hours and having an overload of work), participants were unable to attend or participate in various personal dimensions - that is spending time with their family or children, participating in leisure or exercise activities or attending religious activities (e.g. prayer meetings). Participants also mentioned that work often hindered personal growth (explore opportunities or spend time on activities that that would enhance the quality of their lives or promote self-growth, for example further studies). The following quote illustrates how participants miss out on their children's activities due to work:

It feels to me that I miss out on Heintjie these days. He is involved in rugby in the afternoons, and he needs to go there, and I can't take off from work every time to take him there. I would also like to be there, and now I miss his sport.

(participant MA3)

Secondly, participants mentioned how their work was influenced by various dimensions in their personal life. Due to certain responsibilities towards their families or extended families (e.g. attending school activities of their children, taking care of sick children or helping family members with 
TABLE 3

Different Forms of Interaction

\begin{tabular}{ll}
\hline Forms of Interaction & Meaning \\
\hline Influence of work on personal dimensions & $\begin{array}{l}\text { Work } \leftrightarrow \text { personal life, e.g. family life, personal time, home life, religious activities, studies, leisure time, exercise } \\
\text { and social activities. }\end{array}$ \\
Influence of personal dimensions on work & $\begin{array}{l}\text { Personal dimensions } \leftrightarrow \text { work, e.g. family, home life, the extended family, leisure time and social activities. } \\
\text { Interaction between various personal dimensions }\end{array}$ \\
$\begin{array}{l}\text { Personal dimensions } \leftrightarrow \text { personal dimensions e.g. family life, studies, social activities, exercise, home life, leisure } \\
\text { time and the extended family. }\end{array}$ \\
Negative integration between work and personal dimensions & $\begin{array}{l}\text { No interaction due to the physical and/or psychological separation of the dimensions; segregation of domains (e.g. } \\
\text { intentionally not thinking about home matters at work or not taking work home); intentional cognitive decisions to } \\
\text { separate various domains. }\end{array}$ \\
\hline Segregation of work and personal dimensions &
\end{tabular}

crises), their work was influenced to some extent. Sometimes participants were unable to attend work or were late for work as a result of these responsibilities (e.g. taking children to the doctor before work). Occasionally, participants were even unable to concentrate at work due to constantly thinking about these demands or responsibilities in their personal life. Sometimes participants were even unable to accept good work opportunities due to their family situation. The following quotes serve as illustration:

Yes, because of my situation and the fact that I am a single mother, I can't really work as I would have wished to work, I can't work as much outside as I would have wished.

(participant PA3)

Sometimes there are things on the farm that I just have to finish first. So when my shift starts, I might be late, because I had to attend to the problems on my farm first.

(participant PA6)

When I participate in my sport, I have to play in the rugby match and then I can't be at work.

(participant PA2)

In addition to the previous two forms of interaction, participants also experienced interaction between various personal dimensions (which excluded the work dimension). It seemed that being involved in several personal dimensions could be experienced as stressful, since participants were expected to attend to various activities and responsibilities within various dimensions in their personal lives. For example, some of the participants were confronted with simultaneous demands in various dimensions, such as attending to the needs of their children while also expected to study. Other participants found it difficult to relax or spend time on leisure activities, because they felt guilty not spending time with family. The following quote illustrates the influence of participants' personal leisure activities (in this case coaching rugby) on their family life:

But the biggest influence at this stage is the rugby, it takes up a lot of time that I had to spend with the children, so the rugby takes my time away from the family.

(participant MA3)

Lastly, some participants separated the dimensions in their personal lives, resulting in minimal interference between work and personal life. Others experienced the interaction between dimensions as omnipresent and integrated and found it very difficult to balance different responsibilities. They also experienced incompatibility between their various roles. A major reason for this complex form of interaction was that participants were often confronted with simultaneous demands in different dimensions of their lives and were unable to prevent the spillover effect between dimensions (e.g. when they experienced deadlines at work and were expected to attend to the needs of their children). Some participants even suggested that the interference was part of life and that spillover between dimensions was inevitable. Other participants indicated that the interaction between dimensions was a juggling of responsibilities and that it was not easy to separate the demands and responsibilities of the various dimensions.

Yes, it is difficult to manage because you are a people person. Sometimes it is difficult to differentiate and to say now I am at home and I don't talk about the work or now I am at work and I don't talk about my personal life, you must be very careful.

(participant ME4)

You can't really separate the two from each other. You should remember that if you are happy at work, you will also be happy at home, if you are happy at home, you will also be happy at work. That is the interaction. But if you are unhappy at home over something personal you will take it to work - there is no way you will be able to separate the two.

(participant MA4)

Conversely, several participants were able to keep the influences between the various dimensions apart, either by means of physical segregation (e.g. not taking work home) or psychological segregation (e.g. not thinking about work when spending time at home or with family). Illustrations of physical and psychological segregation include:

I physically don't take work home, it is a principle in my work. I don't take work home, because I feel I have eight hours at work to work and do my part, if it is time to go home, the time is for my family and home.

(participant EA11) (physical)

But like I said, when I am at home, I don't bring work with me. That thing will stay on my mind, because I haven't shared it with someone, but I try to focus and I try not to let my children see what is going on with me. I try to focus only on my home.

(participant ME12) (psychological)

In all the abovementioned forms of interaction, participants mainly referred to the negative influences between the dimensions. Although the negative forms of interaction were more prevalent, few participants indicated positive interaction between dimensions. These positive influences mostly entailed the supportive aspects between dimensions (e.g. having a supportive spouse to communicate with about work-related issues or to help with domestic matters). Illustrating these supportive positive influences between personal dimensions and work:

Well, for me, I think I am blessed to have my husband, because he is involved in everything; actually he prefers to do the groceries. If I'm lecturing till late, he doesn't mind. He will go on a ride with my son and then he does the groceries. We cook together. If our helper is on leave or whatever, we will clean the house together; he will be scrubbing the floor, and I will be doing the dishes.

(participant EE5)

\section{Theme 4: Consequences associated with the various forms of interaction}

The last major theme that emerged from the responses related to the consequences associated with the interaction. It seemed that specific consequences were related to the different forms of interaction, as Table 4 indicates.

Participants mentioned various consequences which related to the various forms of interaction as well as more general consequences relating to the overall interaction being experienced. Although participants mentioned specific consequences 
relating to the various forms of interaction, it seemed that consequences such as time-based consequences, mental preoccupation, spillover of emotions and energy depletion were especially present:

Yes, there are times when you are away from home for a long time, and then it feels like the time is passing by, where you miss out on things. You miss being with your family, you miss your child's rugby game, which is important. But you just can't be there.

(participant MA1)

It's a problem in that even though we are supposed to go out as a family somewhere during the holidays, we can't, this time they've been creating these workshops during our time of the holidays you see.

(participant TE5)

At some stage the other consequences are, I neglected my studies because of church and work, and I quitted a little bit from church.

(participant EE4)
Participants also found it very difficult to concentrate on a specific dimension in their life at one specific time, seeing that while they were occupying a specific dimension they were thinking about or are mentally preoccupied with another dimension. It seemed that participants were sometimes confronted with problems in either their work environment or their personal life and as a result they were unable to focus on the present demands in a specific dimension (e.g. making mistakes in your work due to lack of concentration).

Unfortunately, school is not a case of coming to work at 8:00 and leaving at 17:00, closing your office door behind you. No, you always have work in the back of your head; there are always papers to draw up or tests to mark.

(participant TA12)

It is because of my work affairs and home affairs, eventually it leads to my mind losing concentration somehow. I can't concentrate, and I make a lot of mistakes and then I have to start

TABLE 4

Consequences associated with the various forms of interaction

\begin{tabular}{|c|c|}
\hline Consequences & Work $\rightarrow$ Personal life interaction \\
\hline Time-based consequences & $\begin{array}{l}\text { Difficulty attending to various activities or role players } \\
\text { in one's personal life due to time constraints; inability } \\
\text { to attend family activities due to lack of time; no } \\
\text { time or limited time available for friends or personal } \\
\text { activities; lack of time to spend on domestic activities } \\
\text { such as cooking and cleaning. }\end{array}$ \\
\hline Mental preoccupation & $\begin{array}{l}\text { Constantly thinking of work; inability to concentrate } \\
\text { on things outside work due to thinking of work- } \\
\text { related matters; overload of information and } \\
\text { pressures/demands within the work environment; } \\
\text { inability to do tasks at home due to preoccupation } \\
\text { with work problems. }\end{array}$ \\
\hline $\begin{array}{l}\text { Build up and spillover of } \\
\text { emotions }\end{array}$ & $\begin{array}{l}\text { Experiencing negative emotions (e.g. anger, } \\
\text { frustration, hopelessness, etc.) at work that spill } \\
\text { over to personal life; inability to control emotions that } \\
\text { built up during the day; feeling irritable and edgy at } \\
\text { home due to things that happened at work; tension } \\
\text { between family members due to emotional tension } \\
\text { that arise from problems at work. }\end{array}$ \\
\hline Energy depletion & $\begin{array}{l}\text { High workload resulting in the total depletion of } \\
\text { energy; experiencing overall exhaustion, fatigue and } \\
\text { tiredness due to long work hours; limited energy left } \\
\text { after work to attend to other activities outside work } \\
\text { (e.g. participating in sports activities); draining of } \\
\text { energy due to the various work demands. }\end{array}$ \\
\hline Strain on relationships & $\begin{array}{l}\text { Unable to attend to spouse/children or friends due to } \\
\text { work obligations causes strain on the relationships; } \\
\text { experiencing conflict in marital relationship; strain on } \\
\text { relationships with friends or children as a result of } \\
\text { not providing enough attention or not attending to } \\
\text { their needs. }\end{array}$ \\
\hline Managing responsibilities & $\begin{array}{l}\text { Shifting of responsibilities between family members; } \\
\text { attaining more responsibilities due to spouse's } \\
\text { workload (e.g. attending to the children when spouse } \\
\text { is working late); unable to perform certain tasks and } \\
\text { responsibilities (e.g. unable to pick up children from } \\
\text { school due to working late or unable to cook dinner } \\
\text { because of work hours). }\end{array}$ \\
\hline
\end{tabular}

Limiting of work

opportunities

Personal life $\rightarrow$ Work

Interaction between personal dimensions

Inability to attend to work activities due to family responsibilities (e.g. attending funerals family responsibilities (e.g. attending funeral during the week); difficult being at work on time due to unforeseen circumstances a home; lack of time to perform work-related tasks because of time spent with family or children.

Thinking of personal demands or problems at work; inability to concentrate at work due to problems in personal life (e.g. worrying about your sick child); overload of information and pressures/demands in personal life. Experiencing certain emotions (e.g. anger frustration, hopelessness) in the persona life and the spillover thereof to work; personal dimensions; tension between family personal dimensions; tension between family
members affecting one's emotions; lack of members affecting one's emotions; lack of happiness at work due to lack of happiness problems at home)

Lack of energy due to responsibilities in personal life (e.g. attending to small children during evenings); feeling tired when going to work due to attending to children the previous evening; total depletion of energy resulting in overall exhaustion, fatigue and tiredness.

nability to control emotions that arise from having various demands and responsibilities in personal life; having simultaneous demands and pressures affecting your emotions; experiences anger, frustration and guilt.

Energy depletion from having too many demands from various roles in personal life; limited energy left after attending to various roles in personal life.

Unable to pursue good work opportunities due to family situation (e.g. single paren can't work long distances away from family); forfeit of certain work opportunities; limiting your career in terms of the type of work due to personal responsibilities or circumstances.

Feeling energised from personal life; having meaningful experiences in personal life resulting in more energy; stimulating personal life experiences; having meaningful personal life experiences; having meaningful
relationships in your personal life that make relationships in
life worthwhile.

Due to the variety and simultaneous demands in personal life, learning of new skills took place (learn more patience; learn interpersonal skills to help with own children, etc.). 
everything from the beginning. So it is time-consuming in my work environment because sometimes I do not finish my work because of lack of concentration.

(participant ME11)

Additionally, participants experienced certain emotions which originated from the work environment or personal life and they also indicated that they found it difficult to control these emotions. Participants also experienced a great deal of guilt and anxiety because of an inability to attend to all the responsibilities in their lives.

It is the same, if you are unhappy at work, when you go home tonight, you will take out your frustrations at home.

(participant MA4)

When you see your wife and children in the afternoon, you should orientate yourself so much. Sometimes it is so difficult and you are so angry from work that you will fight with someone from home, even if he doesn't deserve it.

(participant TA4)

Your whole life revolves around feelings of guilt, since all you do is try to solve everything at home, you feel guilty because you don't have enough time to be with the children and also at work you have to solve everything since you don't spend enough time at work.

(participant EA10)

Furthermore, participants indicated how the interaction influenced their levels of energy. Due to all the various demands and pressures, participants seemed to experience a lack of energy which led to feelings of fatigue and exhaustion.

... and the workload too, it will influence you very much. Because you have high workload, you will have less time for your family because if you get home you are just so tired.

(participant TA5)

You feel tired. I feel I am not up to my top function now, because at this stage I am just so tired, chronically tired.

(participant EA10)

When I arrive at home, I am tired, I have to look after the children. Children need this and that and to be guided at school. My mind got so exhausted, so this gives me stress.

(participant PE1)

Regarding more specific consequences related to the influences of work on personal life, participants mentioned strain on their relationships and the process of managing responsibilities. It seemed that participants were unable to invest quality time into their relationships due to work obligations. Participants also mentioned that they were unable to maintain good relationships seeing that they did not give enough attention to these specific relationships (e.g. not giving enough attention to your spouse or children due to high workload and long work hours). Furthermore, due to work obligations such as working overtime or long hours, participants sometimes found it difficult to perform all their responsibilities at home, and as a result responsibilities were shifted between different role players (e.g. when the one spouse [wife] is not able to help with the children in the evenings or not at home on time to cook dinner for the family, the responsibilities are shifted towards the other spouse [father]).

TABLE 5

General consequences associated with the various forms of interaction

\begin{tabular}{ll}
\hline General consequences & Symptoms \\
\hline Psychological health & $\begin{array}{l}\text { Feeling demoralised by all the demands in } \\
\text { life; feeling discouraged in the process of } \\
\text { attempting to balance the interaction; suffering } \\
\text { from depression; feeling anxious about all the } \\
\text { various demands and responsibilities; feeling } \\
\text { tensed and stressed all the time; experiencing } \\
\text { insomnia; having less time to sleep. }\end{array}$ \\
Physical health & $\begin{array}{l}\text { Being sick and experiencing health symptoms } \\
\text { such as chronic headaches, body aches, } \\
\text { shoulder pains, back pains, high blood } \\
\text { pressure, etc. }\end{array}$ \\
Absenteeism or turnover intention & $\begin{array}{l}\text { Absenteeism from work; considering resigning } \\
\text { from work; considering changing occupations }\end{array}$
\end{tabular}

People resigned in the same year that I had to take over, and it also frustrated my family life, because half of the time-actually I spend most of my time at the office and I have a daughter, who is still very young. She still needs me, and it became very, very difficult for her, and very difficult for me.

(participant EE9)

Sometimes after a few hours, you realise but you are wrong-your wife is uncomfortable, and it is not her fault. Then I go to her and apologise and say I was wrong to be nasty with her.

(participant MA2) (strain in relationships)

At this stage I am very lucky, I work permanently till 16:30, but sometimes it happens that I have to work late, and that throws everything out - because dad has to pick up the children then, and he should cook, and give them their baths.

(participant PA7) (managing responsibilities)

Although the majority of consequences suggested a more negative connotation, participants did indicate how having a personal life was very meaningful and resulted in the generation of energy. Participants also mentioned that they learned new skills by participating in various dimensions in their personal lives. It seemed that sometimes participants felt more energetic when engaging in positive relationships in their personal life. Participants indicated that the skills they learned (e.g. learning to be more patient) when taking part in one dimension often transferred to another dimension.

Even when I wake up at home in the morning to go to work, I find that I am energetic from home. So that I perform my duties happily.

(participant PE6)

Finally, more general consequences were mentioned by participants, including influences on their physical and psychological health and their intention to quit their jobs (see Table 5). Participants seemed to suffer from problems such as headaches, body aches and constantly being stressed and tense. Some participants even reported experiencing problems sleeping. For some, the interaction between work and personal life became so unbearable that the thought of leaving their work or occupation became tempting.

It influences you in terms of stress and in terms of physical tenseness. Sometimes you feel the emotions building up and you feel it physically in your shoulders, you feel it in your back, you feel it in you mind. You can also say you feel the stress in terms of your blood pressure being a little high.

(participant MA6)

\section{DISCUSSION}

The field of work-family research has progressed substantially over the past few decades, providing researchers with various integrative frameworks regarding the interaction between work and personal life. The majority of these frameworks include various forms of interaction, related antecedents and consequences as well as the conceptualisation and measurement of the interaction (Allen et al., 2000; Bellavia \& Frone, 2003; Frone, 1992b; Frone, 2003; Geurts \& Demerouti, 2003). Although these frameworks and research findings are well established internationally, the aim of this study was to explore the interaction between work and personal life within a South African context and framework. With this exploratory study, very similar findings as well as unique contributions were made to existing work-family research, relating to the experiences in the workplace and personal life, the various forms of interaction and the consequences of the interaction between work and personal life.

Compared with previous research, similar findings were found with regard to employees' experiences in the workplace, as well as the various antecedents and consequences related to the interaction between their work and personal lives. South African employees experienced similar antecedents (categorised as job characteristics in international literature: Ballout, 2008; Byron, 
2005; Carnicer et al., 2004; Geurts \& Demerouti, 2003), including stressors (e.g. pressure, overload, workload, stressful work arrangements and difficult relationships at work) and resources (e.g. supportive work arrangements and relationships at work). This is in line with previous international research on the Job Demands-Resources (JD-R) model of work-related wellbeing. According to the JD-R model, job characteristics can be categorised into certain job demands and job resources, which could influence the well-being of workers (Demerouti, Bakker, Nachreiner \& Schaufeli, 2001). Job demands is the degree to which the working environment contains stimuli that require some effort and that could lead to negative consequences if they require additional effort beyond the usual way of achieving goals (Demerouti et al., 2001; Jones \& Fletcher, 1996). Although job demands are not necessarily negative, they may turn into job stressors when meeting those demands requires high effort (Schaufeli \& Bakker, 2004).

Given, that the participants in this study were representative of various language groups and various industries, a variety of stressors and resources were identified as being more occupation specific. Overall, however, the stressors mentioned in this study are in line with the job demands identified by Demerouti et al. (2001) - that is physical workload, time pressures, physical environment, shift work and recipient contact. Job resources refers to the degree in which the working environment contains physical, psychosocial or organisational aspects that may be functional in meeting task requirements (e.g. supervisory support, job control and participation) (Schaufeli \& Bakker, 2004). In this regard, participants indicated that having supportive relationships at work or having certain work arrangements is functional in performing their work tasks.

In line with previous findings, South African employees also experienced comparable consequences as a result of the interaction between work and personal life. A variety of the general consequences mentioned by South African employees (e.g. physical symptoms such as headaches or body aches, anxiety and insomnia, absenteeism and turnover intentions) are very similar to categorised consequences in international research (i.e. physical, psychological, behavioural, attitudinal, organisational consequences or work, non-work and healthrelated consequences) (Allen et al., 2000; Bellavia \& Frone, 2003; Geurts \& Demerouti, 2003).

Apart from the abovementioned similarities with previous research, very unique contributions were also made to workfamily research with the exploratory nature of this study. Several valuable unique insights were obtained regarding employees' experiences of their work (e.g. experiencing work as a calling), personal life and the specific way in which they perceive the interaction between these domains (e.g. work influencing personal dimensions, and vice versa) as well as the related consequences (e.g. general and specific consequences).

Regarding the experiences in their work environments (although subjected to various stressful aspects and pressures in their work), some South African employees experienced their work as a fulfilling calling in their life. According to Wrzesniewski, McCauley, Rozin and Schwartz (1997), individuals may experience their work as a calling when they do not work for financial gain but rather for the fulfilment that it brings. Alternatively, some individuals work because they are of the opinion that it is a religious calling for them, while others find it to be socially valuable. Wrezesniewski et al. (1997) also state that although having a calling for your work is not seen as occupation specific, one might expect this calling in more individuals who work in occupations such as education and public safety (i.e. police) where they believe that their work contribute to making the world a better place.

Unique contributions were also made with regard to participants' experiences of their personal life, where employees indicated various areas or domains which were important or beneficial to them. Although previous researchers (Aryee, 1992; Frone, 2003) have expressed the need to regard employees not merely as workers but also to recognise the other domains/areas in their personal lives, this was not the case in most previous work-family interaction studies (which focused primarily on the interference of work with specific domains). In this study, however, participants described the interaction of work with their personal lives by elaborating on various dimensions (e.g. religion, socialising, participating in leisure and exercise activities, studies and home life) and the supportive role of some of these dimensions (i.e. family, religion/spirituality, socialising and exercise). Also, some additional interesting personal dimensions were mentioned which are rarely addressed in previous work-family research, including the existence and importance of an extended family, one's community and the religious/spiritual component.

This notion that work interacts with various areas in individuals' personal life is supported by Swindle and Moos (1992), who state that life offers a wealth of potential domains within which a person can realise a variety of personal agendas. These different domains may each fulfil different goals or needs and could consist of many activities with one's spouse, children, extended family, work or friends. In the South African context, employees seem to particularly value their personal dimensions for either, (1) the support they receive from role players in these dimensions (e.g. the support from family members or friends) or (2) the intrinsic value derived from participating in these dimensions (e.g. religion/spirituality, exercise and leisure activities). Even though the role of support has been addressed by previous work-family researchers, the emphases were mainly on the role of support in either the work or family domains (Carlson \& Perrewe, 1999; Luk \& Schaffer, 2005; Matsui, Oshawa \& Onglatco, 1995; Nasurdin \& Hsia, 2008). Kirrane and Buckley (2004) did investigate support originating from a variety of sources such as colleagues, workplace supervisors, non-work friends, spouse-partner, and extended family, but found only spouse-partner support to be of significance. South African employees, however, indicated the additional support derived from personal dimensions such as religion/spirituality, exercise or socialising outside work.

These abovementioned personal dimensions or areas in individuals' personal lives also contributed to unique findings regarding the interaction experienced by employees within the South African context. Unlike previous international workfamily studies (which focused mainly on the influences of the work domain on the family life - see overviews by Allen et al., 2000 and Eby et al., 2005), participants in the South African context seem to specify not merely the influences of work on family life, but also on a variety of other areas in their personal life. With the exception of a few studies (Aryee, 1992; Holahan \& Gilbert, 1979), the lack of findings from previous studies in this regard could mainly be contributed to the quantitative nature of these studies where the family domain was the only possible personal dimension or domain being measured. Since the methodological nature of this study did not limit individuals to predetermined interaction categories commonly found in the work-family literature (such as time-, strain- or behaviour-based work-family interference), participants were unreservedly able to describe how their work influenced the various dimensions in their personal life.

In addition, South African employees also indicated influences of the various dimensions (e.g. extended family, leisure time, social activities, home life) on their work domain, suggesting a two-directional relationship of interaction. Although a twodirectional interaction relationship is in accordance with previous research (Frone, Russel \& Cooper, 1992a; Geurts et al., 2005; Mesmer-Magnus \& Viswesvaran, 2005; Netemeyer et al., 1996), the role of specific personal dimensions as a source of influence or as dimensions being influenced, became more 
evident. Also, participants described both negative and positive influences between dimensions, which are in accordance with previous negative and positive work-family interaction or family-work interaction research (Greenhaus \& Beutell, 1985; Hanson, et al., 2006; Kinnunen, Feldt, Geurts \& Pulkkinen, 2006; Premeaux et al., 2007; Stevens, et al., 2007; Wayne, Grzywacz, Carlson \& Kacmar, 2000).

Different from previous positive interaction research, the positive influences in this study, seem to merely indicate the more supportive aspects in the various areas of individuals personal lives and the supportive role of these dimensions in employee's lives. Supplementary to the latter, another finding mentioned by participants was the interaction or influences of various personal dimensions with each other, irrespective of the work domain. These findings suggest an additional form of interaction outside the scope of work-family research, where different personal domains are in interaction.

While the majority of previous views of work-family interaction entailed either the direction (i.e. work influencing family life or family life influencing work), quality of influence (i.e. negative or positive) or various forms of interaction (i.e. time-, strain- or behaviour-based interaction) (Bellavia \& Frone, 2003 Frone, 2003; Geurts \& Demerouti, 2003), interesting views on the experiences of interaction were revealed - that is negative integration and segregation between work and personal life. Where some individuals experienced the interference or influences between work and personal life as omnipresent with no proper balance or integration (labelled negative integration), other employees seemed to maintain total separation between their work and areas in their personal life (labelled segregation). For many South African employees, no interaction exists between their work and personal life due to their own physical or psychological attempts or intentions to keep areas in their personal life apart. Although a theoretical perspective of segregation between domains has been hypothesised in earlier research by Dubin and Champoux (1977), more recent views seem to differ. According to Geurts and Demerouti (2003), hardly any evidence exists for a theoretical segregation approach since segregation does not occur naturally but is merely the result of workers' active attempts to prevent work from intruding in their family life. Olson-Buchanan and Boswell (2006) continue by suggesting that the integration or the segregation of work and non-work roles are very much related to the boundaries set by individuals regarding their work and the other areas in their personal life.

Final unique contributions worth mentioning are the various consequences relating to the various forms of interaction that South African employee's experience. Although several consequences were consistently associated with all the forms of interaction (i.e. time-based consequences, energy depletion, spillover of emotions), participants did indicate some consequences which are uniquely related to specific forms of interaction and which are also different from previous work family research (e.g. mental preoccupation as a result of work influencing personal life; limiting of career opportunities as a result of personal influences on work; strain on relationships as a result of work influencing personal life).

Notwithstanding the contributions and information gained from this study, this study was only conducted among certain language groups and occupational groups, where the majority of participants were living in suburbs in large cities or towns. Since circumstances may differ between urban and rural areas, it might be that participants working a rural areas or communities experience their interaction very differently. Also, participants were located only in two of the provinces in South Africa (i.e. North-West and the Free State), thus a question of representation could be asked. In addition to occupation and provincial differences, participants from other language groups might also have different experiences.
Notwithstanding the limitations of the study, recommendations can be made for future research. Although the participants in this study included various language and occupational groups in order to have a representative South African employee sample, it was not the objective of the study to investigate possible differences between the various language and occupational groups. However, some of the experiences obtained regarding the stressors and resources experienced might have been language or occupation specific, which should be addressed in future research. Therefore, it is recommended that differences regarding work-personal life interaction for various language or occupational groups be investigated to determine if the experiences found in this study were language or occupation specific and if they were a fair representation of South African employees.

With the information gained in this study it is recommended that researchers continue to investigate the interaction between the work domain and all other facets in employees' personal lives. The information regarding the specific personal dimensions might be helpful in the development of a more comprehensive measuring instrument for work-personal life interaction. This instrument could include the interaction between not only the work and family domains, but also other domains, and could prove to be very useful in future quantitative studies. It is therefore recommended that future quantitative studies regarding the non-work interface include, apart from the family dimension, other personal dimensions such as religion, leisure and home life.

Moreover, better methodological and research design approaches are recommended, where instead of asking only employees about their experiences, it is important to have several sources of information from both domains, for instance, from the partner and adolescent child(ren), supervisors or observers (Geurts \& Dikkers, 2002). Moreover, the profound information regarding the pressures of the work environments in South Africa could be useful for organisations and for future organisation intervention research.

\section{Conclusion}

To conclude, this study contributed to a better understanding of how South African employees experience the interaction between their work and personal life. Although they experience very similar stressors and supportive aspects in their work and very similar forms of interaction, South African employees do experience some aspects in their workplace and personal life differently. With the exploratory nature of this study, it was possible to gain more insight into individuals' personal life and to gain a better understanding of the various personal dimensions that South African employees value (e.g. community, religion/spirituality, leisure, exercise). These dimensions also seem to have a unique influence on their work, and vice versa, contributing to unique forms of interaction and related consequences. Some South African employees seem to experience consequences such as mental preoccupation, limiting of career opportunities, energy generation and learned skills which are very unique to previous work-family research.

\section{REFERENCES}

Allen, T.D., Herst, D.E.L., Bruck, C.S., \& Sutton, M. (2000). Consequences associated with work-to-family conflict: A review and agenda for future research. Journal of Occupational Health Psychology, 5(2), 278-308.

Appleton, J.V. (1995). Analysing qualitative interview data: Addressing issues of validity and reliability. Journal of Advanced Nursing, 22, 993-997.

Aryee, S. (1992). Antecedents and outcome of work-family conflict among married professional women: Evidence from Singapore. Human Relations, 45, 813-837. 
Bailyn, L., \& Harrington, M. (2004). Redesigning work for workfamily integration. Community, Work \& Family, 7(2), 197-208.

Ballout, H.I. (2008). Work-family conflict and career success: The effects of domain-specific stressors. Journal of Management Development, 27(5), 437-446.

Barnette, R.C., \& Burach, G. K. (1985). Women's involvement in multiple roles and psychological distress. Journal of Personality and Social Psychology, 49, 135-145.

Bellavia, G.M., \& Frone, M.R. (2003). Work-family conflict. In J. Barling, E.K. Kelloway \& M.R. Frone (Eds.), Handbook of Stress, (pp. 113-148). Thousand Oaks: Sage.

Bulger, C.A., Matthews, R.A., \& Hoffman, M.E. (2007). Work and personal life boundary management: Boundary strength, work/personal life balance, and the segmentationintegration continuum. Journal of Occupational Health Psychology, 12(4), 365-375.

Burnard, P. (1991). A method of analysing interview transcripts in qualitative research. Nurse Education Today, 11, 461-466.

Burns, N., \& Grove, S.K. (1997). The practice of nursing research: Conduct, critique and utilization. (3rd edn.). Philadelphia: WB Saunders.

Byron, K. (2005). A meta-analytic review of work-family conflict and its antecedents. Journal of Vocational Behavior, 67, 169-198.

Cariku, I. (2002, May). Gender differences in work family conflict among men in Turkey: Non western perspectives. Paper presented at the European Academy of Management conference, Stockholm, Sweden.

Carlson, D.S., \& Kacmar, K.M. (2000). Work-family conflict in the organization: Do life role values make a difference? Journal of Management, 26, 1031-1054.

Carlson, D.S., Kacmar, K.M., \& Williams, L.J. (2000). Construction and initial validation of a multidimensional measure of workfamily conflict. Journal of Vocational Behavior, 56, 249-276.

Carlson, D.S., \& Perrewe, P.L. (1999). The role of social support in the stressor-strain relationship: An examination of work-family conflict. Journal of Management, 25(4), 513-540.

Coetzer, L. (2006). Work-home interaction of South African working females. Unpublished master's dissertation, North-West University, Potchefstroom, South Africa.

Curbow, B., McDonell, K., Spratt, K., Griffen, J., \& Agnew, J. (2003). Development of the work-family interface scale. Early Childhood Research Quarterly, 18, 310-330.

De Klerk, M., \& Mostert, K. (2010). Work-home interference: Examining socio-demographic predictors in the South African context. South African Journal of Human Resource Management, 8, 1-10.

Demerouti, E., Bakker, A.B., Nachreiner, F., \& Schaufeli, W.B. (2001). The job demands-resources model of burnout. Journal of Applied Psychology, 86(3), 499-512.

De Vos, A.S., Strydom, H., Fouche, C.B., \& Delport, C.S.L. (2005). Research at Grass roots: For the social sciences and human service professions. Pretoria: Van Schaik Publishers.

Donald, F., \& Linington, J. (2008). Work/family border theory and gender role orientation in male managers. $S A$ Journal of Psychology, 38(4), 659-671.

Dubin, R., \& Champoux, J.E. (1977). Central life interests and job satisfaction. Organisational Behavior and Human Performance, 18, 366-377.

Eby, L.T., Casper, W.J., Lockwood, C.B., Bordeaux, C., \& Brinley, A. (2005). Work and family research in IO/OB: Content analysis and review of the literature (1980-2002). Journal of Vocational Behavior, 66, 124-197.

Elkins, D.N. (1988). Towards a humanistic-phenomenological spirituality: Definition, description, and measurement. Journal of Humanistic Psychology, 28, 5-18.

Emmons, R.A. (2006). Spirituality, recent progress. In M. Csikszentmihalyi \& I.S. Csikszentmihalyi (Eds.), A life worth living, contributions to positive psychology, (pp. 62-80). New York: Oxford University Press.

Frone, M.R. (2003). Work-family balance. In J.C. Quick \& L.E. Tetrick (Eds.), The Handbook of Occupational Health Psychology, (pp. 143-162). Washington: American Psychological Association.
Frone, M.R., Russel, M., \& Cooper, M.L. (1992a). Prevalence of work-family conflict: Are work and family boundaries asymmetrically permeable. Journal of Organisational Behavior, 13(7), 723-729.

Geurts, A.R., \& Dikkers, S.E. (2002, May). The work-nonwork interface: What do we know and where should we go? Paper presented at the European Academy of Management conference, Stockholm, Sweden.

Geurts, S.A.E., \& Demerouti, E. (2003). In M.J. Schabracq, J.A.M. Winnubst, \& C.L. Cooper (Eds.), The handbook of work and health psychology, (pp. 280-312). Chichester: Wiley.

Geurts, S.A.E., Taris, T.W., Kompier, M.A.W., Dikkers, J.S.E., Van Hooff, L.M., \& Kinnunen, U.M. (2005). Work-home interaction from a work psychological perspective: Development and validation of a new questionnaire, the SWING. Work and Stress, 19(4), 319-339.

Greenhaus, J.H., \& Beutell, N.J. (1985). Sources of conflict between work and family roles. Academy of Management Review, 10, 76-88.

Greenhaus, J.H., Collins, K.M., \& Shaw, J.D. (2003). The relation between work-family balance and quality of life. Journal of Vocational Behavior, 63, 510-531.

Greenhaus, J.H., \& Parasuraman, S. (1999). Research on work, family, and gender: Current status and future directions. In G.N. Powell (Ed.), Handbook of gender and work, (pp. 391-412). Newbury Park: Sage.

Grzywacz, J.G., \& Marks, N.F. (2000). Reconceptualizing the work-family interface: An ecological perspective on the correlates of positive and negative spillover between work and family. Journal of Occupational Health Psychology, 5(1), 111-126.

Guba, E.G. (1981). Criteria for assessing the trustworthiness of naturalistic inquiries. Educational Resources Information Centre Annual Review Paper, 29, 75-91.

Guba, E.G., \& Lincoln, Y.S. (1994). Competing Paradigms in Qualitative Research. In N.K. Denzin \& Y.S. Lincoln (Eds). Handbook of qualitative research, (pp. 105-117). Thousand Oaks: Sage.

Hanson, G.C., Hammer, L.B., \& Colton, C.L. (2006). Development and validation of a multidimensional scale of perceived work-family positive spillover. Journal of Occupational Health Psychology, 11(3), 249-265.

Haworth, J., \& Lewis, S. (2005). Work, leisure and well-being. British Journal of Guidance and Counselling 33(1), 67-79.

Hill, P.C. (1999). Giving religion away: What the study of religion offers psychology. International Journal for the Psychology of Religion, 9, 229-249.

Hill, P.C., Pargament, K.I., Wood, R.W., Mccullough, M.E., Swyers, J.P., Larson, D.B. et al. (2000). Conceptualizing religion and spirituality: Points of commonality, points of departure. Journal for the Theory of Social Behavior, 30, 51-77.

Holahan, C.K., \& Gilbert, L.A. (1979). Conflict between major life roles: Women and men in dual-career couples. Human Relations 32(6), 451-467.

Hsieh, H., \& Shannon, S.E. (2005). Three approaches to qualitative content analysis. Qualitative Health Research, 15, $1277-1288$.

Jorgenson, L.I., \& Rothmann, S (2008). Occupational stress, ill health and organisational commitment of members of the South African Police Service in the North-West Province. Acta Criminology, 21(2), 1-15.

Keene, J.R., \& Reynolds, J.R. (2005). The job costs of family demands, gender differences in negative family-to-work spillover. Journal of Family Issues, 26(3), 275-299.

Kinnunen, U., Feldt, T., Geurts, S., \& Pulkkinen, L. (2006). Types of work-family interface: Well-being correlates of negative and positive spillover between work and family. Scandinavian Journal of Psychology, 47, 149-162.

Kirchmeyer, C. (1992). Perceptions of non-work to work spillover: Challenging the common view of conflict-ridden domain relationships. Basic and Applied Social Psychology, 13(2), 231-249. 
Kirrane, M., \& Buckley, F. (2004). The influence of support relationships on work-family conflict: Differentiating emotional from instrumental support. Equal Opportunities International, 23, 78-97.

Koekemoer, F.E., \& Mostert, K. (2006). Job characteristics, burnout and negative work-home interference. South African Journal of Industrial Psychology, 32(3), 87-97.

Kvale, S. (1996). Interviews: An introduction to qualitative research interviewing. Thousand Oaks: Sage.

Lewis, S., \& Cooper, C.L. (1999). The work-family research agenda in changing contexts. Journal of Occupational Health Psychology, 4(4), 382-393.

Lewis, S., \& Cooper, C. (2005). Work-Life Integration: Case studies of organisational change. Chichester: Wiley.

Lewis, S., Rapoport, R., \& Gambles, R. (2003). Reflections on the integration of paid work and the rest of life. Journal of Managerial Psychology, 18, 824-841.

Lingard, H., \& Francis, V. (2005). Does work-family conflict mediate the relationship between job schedule demands and burnout in male construction professionals and managers? Construction Management and Economics, 23, 733-745.

Lombaard, A., \& Mouton, J. (2005). Chronic fatigue syndrome, the body and the self: A qualitative analysis. South African Journal of Psychology, 35(2), 286-307.

Luchetta, T. (1995). Parental and work role salience, every day problems, and distress: A prospective analysis of specific vulnerability among multiple role women. Woman $\mathcal{E}$ Health, 22(4), 21-49.

Luk, D.M., \& Shaffer, M.A. (2005). Work and family domain stressors and support: Within-and cross-domain influences on work-family conflict. Journal of Occupational and Organizational Psychology, 78(4), 489-508

Marais, C., Mostert, K., Geurts, S.A.E., \& Taris, T.W. (2009) The psychometric properties of a translated version of the Survey Work-home Interaction - Nijmegen (SWING) Instrument. South African Journal of Psychology, 39, 202-219.

Marler, P.L., \& Hadaway, C.K. (2002). 'Being religious' or 'being spiritual' in America: A zero-sum proposition? Journal for the Scientific Study of Religion, 41, 289-300.

Matsui, T., Oshawa, T., \& Onglatco, M. (1995). Work-family conflict and the stress-buffering effects of husband support and coping behaviour among Japanese married working women. Journal of Vocational Behavior, 47, 178-192.

McClellan, K., \& Uys, K. (2009). Balancing dual roles in selfemployed women: An exploratory study. SA Journal of Industrial Psychology, 35, 1-10.

Mesmir-Magnus, J.R., \& Viswesvarum, C. (2005). Convergence between measures of work-to-family and family-to-work conflict: A meta-analytic examination. Journal of Vocational Behaviour, 67, 215-232.

Mostert, K., Cronjé, S., \& Pienaar, J. (2006). Job resources, work engagement and the mediating role of positive work-home interaction of police officers in the North West Province. Acta Criminologica, 19(3), 64-87.

Mostert, K., \& Oldfield, G. (2008). Work-home interaction of employees in the mining environment. South African Journal of Economic and Management Sciences, 12(1), 81-99.

Mostert, K., \& Rathbone, A.D. (2007). Work characteristics, work-home interaction and engagement of employees in the mining industry. Management Dynamics, 16(2), 36-52.

Mostert, F.F., Rothmann, S., Mostert, K., \& Nell, K. (2008). Outcomes of occupational stress in higher education institution. Southern African Business Review, 12(3), 102-127.

Nasurdin, A.M., \& Hsia, K.L. (2008). The influence of support at work and home on work-family conflict: Does gender make a difference? Research and Practice in Human Resource Management, 16(1), 18-38.

Netemeyer, R.G., Boles, J.S., \& McMurrian, R. (1996). Development and validation of work-family conflict and family-work conflict. Journal of Applied Psychology, 81(4), 400-410.
Okun, B.F. (1992). Effective helping interviewing and counselling techniques (4th edn). California: Brooks/Cole.

Olson-Buchanan, J.B., \& Boswell, W.R. (2006). Blurring boundaries: Correlates of integration and segmentation between work and nonwork. Journal of Vocational Behavior, $68,432-445$.

Oosthuizen, T.F.J., \& Berndt, A.D. (2008). Stress management behaviour among academic employees. Journal of Contemporary Management, 5, 90-105.

Parasuraman, S., \& Greenhaus, J.H. (2002). Toward reducing some critical gaps in work-family research. Human Resource Management Review, 12, 299-312.

Pargament, K.I. (1999). The psychology of religion and spirituality? Yes or no. International Journal for the Psychology of Religion, 9, 3-16.

Patel, C.J., Govender, V., Paruk, Z., \& Ramgoon, S. (2006). Working mothers: Work-family conflict, job performance and family/work variables. SA Journal of Industrial Psychology, 32(2), 39-45.

Pienaar, J., \& Rothmann, S. (2006). Occupational stress in the South African Police Service. SA Journal of Industrial Psychology, 32(3), 72-78.

Pieterse, M., \& Mostert, K. (2005). Measuring work-home interaction: Validation of the survey work-home interaction-Nijmegen (SWING) Instrument. Management Dynamics, 14(2), 2-15.

Pietromonaco, P.R., Manis, J., \& Frohardt-Lane, K. (1986). Psychological consequences of multiple roles. Psychology of Women Quarterly, 10, 373-382.

Plaisier, I., De Bruijn, J.G.M., Smit, J.H., De Graaf, R., Ten Have M., Beekman, A.T.F. et al. (2008). Work and family roles and the association with depressive and anxiety disorders: Differences between men and women. Journal of Affective Disorders, 105, 63-72

Polach, J. (2003). HRD's role in work-life integration issues: Moving the workforce to a change in mindset. Human Resource Development International, 6(1), 57-68.

Premeaux, S.F., Adkins, C.L., \& Mossholder, K.W. (2007) Balancing work and family: A field study of multidimensional, multi-role work-family conflict. Journal of Organizational Behaviour, 28, 705-727.

Roberts, K. (1999). Leisure in contemporary society. Wallingford CABI.

Rost, I., \& Mostert, K. (2007). The interaction between work and home of employees in the earthmoving equipment industry: Measurement and prevalence. SA Journal of Industrial Psychology, 33(2), 54-61.

Salkind, N.J. (2009). Exploring Research (7th edn.). Upper Saddle River: Prentice Hall.

Schaufeli, W.B., \& Bakker, A.B. (2004). Job demands, job resources, and their relationship with burnout and engagement: A multi-sample study. Journal of Organizational Behaviour, 25, 293-315.

Small, S.A., \& Riley, D. (1990). Toward a multidimensional assessment of work spillover into family life. Journal of Marriage and Family, 52, 51-61.

Stevens, D.P., Minnotte, K.L., Mannon, S.E., \& Kiger, G. (2007). Examining the 'neglected side of the work-family interface': Antecedents and positive and negative family to work spillover. Journal of Family Issues, 28, 242-262.

Swindle, R.W., \& Moos, R.H. (1992). Life domains in stressors, coping and adjustment. In W.B. Walsh., K.H. Craik. \& R.H. Price. (Eds.) Person-environment psychology, models and perspectives, (pp. 1-33). Hillsdale: Erlbaum.

Thompson, J.A., \& Bunderson, J.S. (2001). Work-nonwork conflict and the phenomenology of time, beyond the balance metaphor. Work and Occupations, 28(1), 17-39.

Voydanoff, P. (2005). The Differential Salience of Family and Community Demands and Resources for Family-to-Work Conflict and Facilitation. Journal of Family and Economic issues, 26(3), 395-417. 
Wayne, J.H., Grzywacz, J.G., Carlson, D.S., \& Kacmar, K.M. (2007). Work-family facilitation: A theoretical explanation and model of primary antecedents and consequences. Human Resource Management Review, 17, 63-76.

Weber, R.P. (1990). Basic content analysis. Beverly Hills: Sage.

Weiss, R.S. (1994). Learning from strangers: The art of and method of qualitative interview studies. New York: The Free Press.

Welman, J.C., Kruger, S.J., \& Mitchell, B. (2005). Research methodology ( 3 rd edn.). Cape Town: Oxford University Press.

White, M.D. \& Marsh, E.E. (2006). Content analysis: A flexible methodology, Library Trends, 55, 22-45.
Willig, C. (2008). Introducing qualitative research in psychology (2nd edn.). New York: McGraw-Hill Education.

Wrzesniewski, A., McCauley, C., Rozin, P., \& Schwartz, B. (1997). Jobs, careers and callings: Peoples's relations to their work. Journal of Research in Personality, 31, 21-33.

Zinnbauer, B.J., Pargament, K.I., Cole, B., \& Rye, M.S. (1997). Religion and spirituality: Unfuzzying the fuzzy. Journal for the Scientific Study of Religion, 36, 549-564.

Zinnbauer, B.J., Pargament, K.I., \& Scott, A.B. (1999). The emerging meanings of religiousness and spirituality: Problems and prospects. Journal of Personality, 67, 889-920. 